\title{
OPERATING AND FINANCIAL LEVERAGE AS RISK MEASURES IN AGRICULTURAL COMPANIES
}

\author{
SERHIY ZABOLOTNYY \\ MIROSEAW WASILEWSKI
}

\begin{abstract}
The goal of the research is to estimate the level of risk of agricultural companies according to degree of operating and financial leverage, and to define relations between these measures and ratios of financial efficiency. The research involved companies from the database of the Institute of Agricultural and Food Economics - National Research Institute in 2005-2013. The greatest impact on risk of agricultural companies had the degree of operating leverage characterizing sensitivity of operating profit on volatility of operating revenue, regarding to cost structure. The degree of financial leverage showing the level of debt and interest paid influenced the risk of agricultural companies to a lesser extent. Agricultural companies with a high degree of total leverage had lower financial efficiency, arising from a low ability to generate operating profit.
\end{abstract}

Keywords: operating leverage, financial leverage, risk, agricultural company.

JEL codes: D81, G32, Q14.

\section{Introduction}

Under market economy conditions, the efficiency of a business entity depends on the managerial ability of its personnel to make effective investment decisions and ensure stable sources of financing. Achievement of the efficiency level that is desirable from the perspective of enterprise owners and managers is determined by the achievement of relations between the expected income from the investment projects and accepted risk that are appropriate for the specific market conditions

Dr Serhiy Zabolotnyy, Szkoła Główna Gospodarstwa Wiejskiego w Warszawie, Wydział Nauk Ekonomicznych, Katedra Finansów; ul. Nowoursynowska 166, bud. 7, p. 1B, 02-787 Warszawa (serhiy_zabolotnyy@sggw.pl). Dr hab. Mirosław Wasilewski, prof. SGGW, Szkoła Główna Gospodarstwa Wiejskiego w Warszawie, Wydział Nauk Ekonomicznych, Katedra Finansów; ul. Nowoursynowska 166, bud. 7, p. 108B, 02-787 Warszawa (miroslaw_wasilewski@sggw.pl). 
(Stępień, 2008). According to the classical financial theory, the relation between the expected profitability and risk is directly proportional (Sharpe, 1964; Wędzki, 2003). The basic concepts of risk are related to the negative and neutral perception of this phenomenon. The negative concept of risk means a possibility of failure to achieve the expected result, while the neutral concept of risk treats it as the possibility of producing a result that differs from the expected one (Jajuga, 2009). In the economic practice, the way risk is treated depends primarily on the attitude of the managers, who are characterised by various preferences and perspectives on risk (Graham and Harvey, 2001; Sołtysiak, 2014). In such an approach, risk is closely connected to behavioural finance, which explains investors' and manager's actions through psychological and social mechanisms (Shiller, 2003; Bąk, 2011). Regardless of the decision makers' approach, risk management in an enterprise requires the management to know its sources and determinants. The correct identification of this phenomenon allows them to use formalised measurement and analysis tools in order to determine the limits of accepted risk, its dynamic and scenarios involving impact of various economic factors, and its relation to the efficiency of the enterprise.

The relation between the profitability and the risk in the business activity to a large extent depends on the specific nature of the sector in which the business entity operates (Peterlik, 2012; Wasilewski and Juszczyk, 2015). In agriculture, the main source of risk is the production risk, which is related to the uncertainty in regard to the quantity and quality of produced goods, price risk resulting from the fluctuations of supply and the low flexibility of demand, and political risk, which determines the targets of financial aid for various agricultural activities. While it determines the profitability of agricultural enterprises, the combination of various risk factors depends on the quality of decisions made by the management only to a limited degree (Sulewski, 2015). Therefore, management of agricultural sector entities results in the necessity to pay particular attention primarily to those risk factors that are within the manager's control, i.e. in the area of operational efficiency and financial security. What is important in the area of operations is margin management taking account of the relevant cost structure, while as regards financing, what should be controlled is the level of debt and the financial burden due to the interest.

Practical risk analysis employs measures of volatility, security, hazard and sensitivity (Nowak, 2009). In such an approach, the volatility of the basic performance categories, such as revenue or operating profit and the sensitivity of financial assets to these changes, can be treated as a point of reference in the assessment of risk in the activity of business entities (Markowitz, 1952). This means, for example, that enterprises with relatively more volatile revenue and higher sensitivity of profit to such changes might be regarded as higher risk entities (Kinnunen, 2013). A comparison of the rate and direction of the response of financial performance to volatility allows the operational and financial risk of a business entity to be parametrised.

In the literature, the sources of the operational risk of an enterprise are sought in the volatility of the operating margin and the level and structure of operating cost (Kowalczyk and Kusak, 2006). Financial risk, in turn, manifests itself in the level of debt and the financial burden of interest (Sierpińska and Jachna, 2007). In practice, 
the measure of the operational risk that characterises the sensitivity of the operating performance of an enterprise to the change in operating revenue taking account of the cost structure, is the degree of operating leverage (Pomykalska and Pomykalski, 2007). High operating leverage indicates high operating risk of an entity due to a higher percentage of fixed costs in the operational cost structure (Jaworski, 2010). Financial leverage is a measure providing information on the financial risk of the enterprise and characterising the volatility of the gross outturn in relation to the operating outturn (Sierpińska and Jachna, 2007). A higher financial leverage suggests a higher percentage of borrowed capital in financing and significant cost of interest, which increases the risk of the enterprise. In the light of this interpretation, management of the enterprise's risk, based on the operating and financial leverage, should boil down to the reduction in the leverage effect to the bare minimum, on the one hand, ensuring a rational structure of operating costs and, on the other, enabling avoidance of high losses due to the seasonality of operating revenue.

\section{Methodology}

The aim of this study is to assess the risk level of agricultural enterprises using operating and financial leverage and to determine the relation between these two measures and the financial efficiency ratios. In this article, financial efficiency is defined as a specific level at which the monetary goals of an enterprise are achieved with particular emphasis on the maximisation of its value as reflected by maximum utility from employment of equity in assets expressed in both in absolute and relative terms, i.e. by ratios (Kulawik, 2008). The financial efficiency of agricultural enterprises was done using profitability ratios. The research was based on the database of the Institute of Agricultural and Food Economics - National Research Institute, which contains financial statements of agricultural enterprises utilising land from the stock of the Agricultural Property Agency (APA) ${ }^{1}$, i.e. companies of the APA and enterprises that bought or leased from the APA. The research covered the period between 2005 and 2013. In the analysed period, the number of the studied agricultural enterprises ranged from 143 to 175 . For specific years in the studied period, the risk of agricultural enterprises was assessed using the degree of operating, financial and total leverage, and the ratios contributing to leverage mechanisms in the studied entities were characterised.In this study, the degree of operating leverage (DOL) was calculated using the following formula:

$$
D O L=\frac{G M}{E B I T}
$$

where:

$G M$ - gross margin,

$E B I T$ - operating profit.

Gross margin was defined as the difference between the operating revenue and the variable costs of agricultural enterprises.

${ }^{1}$ In 2017, the Agricultural Property Agency and the Agricultural Property Agency were replaced by the National Support Centre for Agriculture. 
In order to present the impact of these two components contributing to the operating leverage of agricultural enterprises, the degree of operating leverage was decomposed into factors according to the formula:

$$
D O L=\frac{G M R}{G M R-F C R}
$$

where:

GMR - gross margin ratio, $F C R$ - fixed costs ratio.

The said ratios were presented using the formulas:

$$
\begin{aligned}
& W M B=\frac{\text { gross margin }}{\text { operating revenue }} \\
& F C R=\frac{\text { fixed costs }}{\text { operating revenue }}
\end{aligned}
$$

The degree of operating leverage depends on the gross margin and fixed costs of the enterprise. mula:

The degree of financial leverage (DFL) was calculated using the following for-

$$
D F L=\frac{E B I T}{E B I T-\text { Interest }}
$$

where:

Interest - the value of the paid net interest ${ }^{2}$.

In order to present the impact of compounds on the degree of financial leverage, the financial leverage formula was transformed in the following way:

$$
D F L=\frac{G M R-F C R}{(G M R-F C R)-I \times \frac{1}{A T} \times\left(1-\frac{1}{E M}\right)}
$$

where:

$I \quad$ - interest rate on borrowed capital ${ }^{3}$.

$A T$ - asset turnover ratio,

$E M$ - equity multiplier.

\footnotetext{
${ }^{2}$ In the literature, the value of interest used for calculating the DFL is most often treated in a simplified manner, as a mean weighted interest rate of borrowed capital (Kowalczyk and Kusak, 2006). Nonetheless, gross profit of an enterprise can be affected by both financial revenue and components of financial costs other than debt interest, e.g. charges due to valuation adjustments of financial assets or exchange losses (Fedak, 2016). Therefore, considering only the interest on borrowed capital in the calculation of the DFL would not reflect the total effect of change to the gross profit compared to operating profit. The authors' approach includes a proposal to calculate net interest as a difference between the total cost and financial revenue.

${ }^{3}$ The ratio was calculated as net interest/borrowed capital.
} 
The asset turnover ratio and equity multiplier were calculated using the following formulas:

$$
\begin{aligned}
& A T=\frac{\text { operating revenue }}{\text { Assets }} \\
& E M=\frac{\text { Assets }}{\text { Equity }}
\end{aligned}
$$

Apart from the gross margin and fixed costs, such as the burden of interest on borrowed capital, the degree of financial leverage is directly affected by the equity to borrowed capital ratio and the enterprise's asset productivity ratio.

The degree of total leverage results from the mutual impact of the degree of operating leverage and the degree of financial leverage. Therefore, the degree of total leverage (DTL) can be expressed using the following formula:

$$
D T L=D O L \times D F L
$$

Figure 1 shows the relation between various degrees of leverage in the enterprise and specific partial ratios and the degree of total leverage.

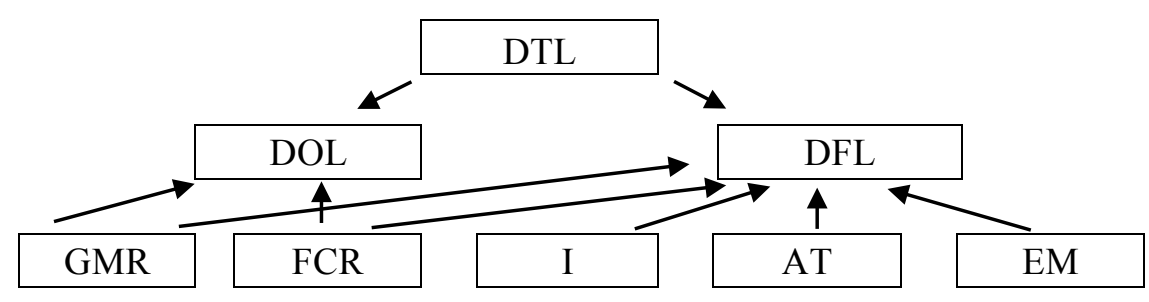

Fig. 1. Relations between the DTL, DOL and DFL and partial leverage ratios of an enterprise. Source: Kowalczyk and Kusak (2006).

Table 1 shows the response of the DTL to changes in partial ratios (ceteris paribus) contributing to this measure in an enterprise. In a situation of profitable activity, the maximum degree of total leverage will be achieved in case of a simultaneous drop in the gross margin and the asset turnover ratio, increase in the ratio of fixed costs to operating revenue, and growth in the interest on borrowed capital and the level of debt of a business entity. 
Table 1

Response of the DTL to changes in partial ratio contributing to leverage in an enterprise

\begin{tabular}{|c|c|c|}
\hline Ratio & Trend & Response of the DTL \\
\hline \multirow{2}{*}{ Gross margin } & growth & drop \\
\hline & drop & growth \\
\hline \multirow{2}{*}{ Fixed costs } & growth & growth \\
\hline & drop & drop \\
\hline \multirow{2}{*}{ Interest rate on borrowed capital } & growth & growth \\
\hline & drop & drop \\
\hline \multirow{2}{*}{ Asset turnover } & growth & drop \\
\hline & drop & growth \\
\hline \multirow{2}{*}{ Equity multiplier } & growth & growth \\
\hline & drop & drop \\
\hline
\end{tabular}

Source: Kowalczyk and Kusak (2006).

In order to present links between the measures of risk and the level of financial efficiency of an enterprise in the structure of the operating leverage and total leverage, the calculations take into account the operating profit ratio (Sibilski, 2010):

$$
D O L=\frac{G M R}{R O P}
$$

where:

$R O P$ - operating profit ratio.

The operating profit ratio can be expressed in the following way:

$$
R O P=\frac{\text { operating profit }}{\text { operating revenue }}
$$

The relation between the DFL and the profitability of an enterprise can be shown using the following formula:

$$
D F L=\frac{R O P}{G P R}
$$

where:

$G P R$ - gross profit ratio.

The gross profit ratio was calculated according to the following formula:

$$
G P R=\frac{\text { gross profit }}{\text { operating revenue }}
$$


The statistical verification of relations related to leverage mechanisms in agricultural enterprises involved calculation of the coefficients of linear correlation between the degrees of leverage and the constituent partial ratios. Furthermore, the correlations between the degrees of leverage and profit ratios were determined, which allowed conclusions to be drawn in regard to the relations between risk assessment parameters and the financial efficiency of agricultural enterprises.

\section{Results}

Table 2 shows degrees of leverage and partial ratios characterising financial mechanisms of agricultural enterprises in 2005-2013. In the studied period, the average degree of total leverage was equal to the 3.77 , the average degree of operating leverage was 3.59 , and the average financial leverage was 1.05 . This means that the risk of agricultural enterprises expressed in terms of degrees of leverage primarily depended on changes in operations. These changes were related to the structure of operating costs, the level of sales revenue, and operating profit. On the other hand, the ratios related to financial leverage were less important from the perspective of the risk of agricultural enterprises. This conclusion is confirmed by the scatterplots of the degree of total leverage (DTL) variable in relation to the degree of operating leverage (DOL) variable and the degree of financial leverage (DFL) (Fig. 2). In the analysed period, the coefficient of correlation between the DTL and DOL variables was 0.7744 , and between the DTL and DFL variables -0.5769 , which indicates a relatively stronger link between the total leverage and the operating leverage than between the former and the financial leverage.

Table 2

Degrees of leverage and partial ratios characterising financial mechanisms of agricultural enterprises

\begin{tabular}{lcccccccccc}
\hline \multirow{1}{*}{\multicolumn{1}{c}{ Parameter }} & \multicolumn{10}{c}{ Year } \\
\cline { 2 - 11 } & 2005 & 2006 & 2007 & 2008 & 2009 & 2010 & 2011 & 2012 & 2013 & Average \\
\hline Operating leverage & 4.01 & 3.95 & 2.90 & 6.20 & 4.40 & 2.85 & 3.54 & 3.28 & 3.76 & 3.59 \\
Financial leverage & 1.12 & 1.10 & 1.06 & 1.20 & 1.15 & 1.03 & 1.00 & 1.02 & 1.04 & 1.05 \\
Total leverage & 4.49 & 4.34 & 3.07 & 7.46 & 5.06 & 2.94 & 3.52 & 3.35 & 3.92 & 3.77 \\
Gross margin ratio (\%) & 39.5 & 36.9 & 40.5 & 37.0 & 38.0 & 41.0 & 40.3 & 40.2 & 40.3 & 39.6 \\
Fixed costs ratio (\%) & 29.6 & 27.6 & 26.5 & 30.6 & 29.1 & 26.7 & 28.9 & 28.0 & 29.6 & 28.6 \\
Interest rate on borrowed & 2.5 & 2.1 & 2.0 & 2.3 & 2.2 & 1.1 & -0.2 & 0.7 & 1.2 & 1.3 \\
capital (\%) & 0.76 & 0.71 & 0.70 & 0.67 & 0.64 & 0.64 & 0.64 & 0.65 & 0.60 & 0.65 \\
Asset turnover ratio & 1.48 & 1.40 & 1.38 & 1.42 & 1.47 & 1.33 & 1.30 & 1.30 & 1.28 & 1.34 \\
Equity multiplier & & & & & & & & & &
\end{tabular}

Source: own study. 
In 2005-2008, the degree of total leverage increased from 4.49 to 7.46 , which suggested a higher risk of agricultural enterprises. In the same period, the degree of operating leverage grew from 4.01 to 6.20 , and the degree of financial leverage increased to 1.20. From the perspective of leverage mechanisms, this indicated the increase in operating and financial risk. Such a phenomenon could to a large extent result from the adjustment of Polish farms to the European Union requirements that manifested in the increase in investment financed from preferential credits (Rosa, 2011). Higher degrees of leverage in 2008, then, were related to the unfavourable macroeconomic situation. The departure from this trend was identified in 2007, when the degree of total leverage was at 3.07, and the degree of operating leverage decreased to 2.90. This resulted from the growth in gross margin and the simultaneous drop in the ratio of fixed costs to operating revenue. In 2009, the degree of total leverage decreased to 5.06, which was still 1.29 higher than the average for the studied period.
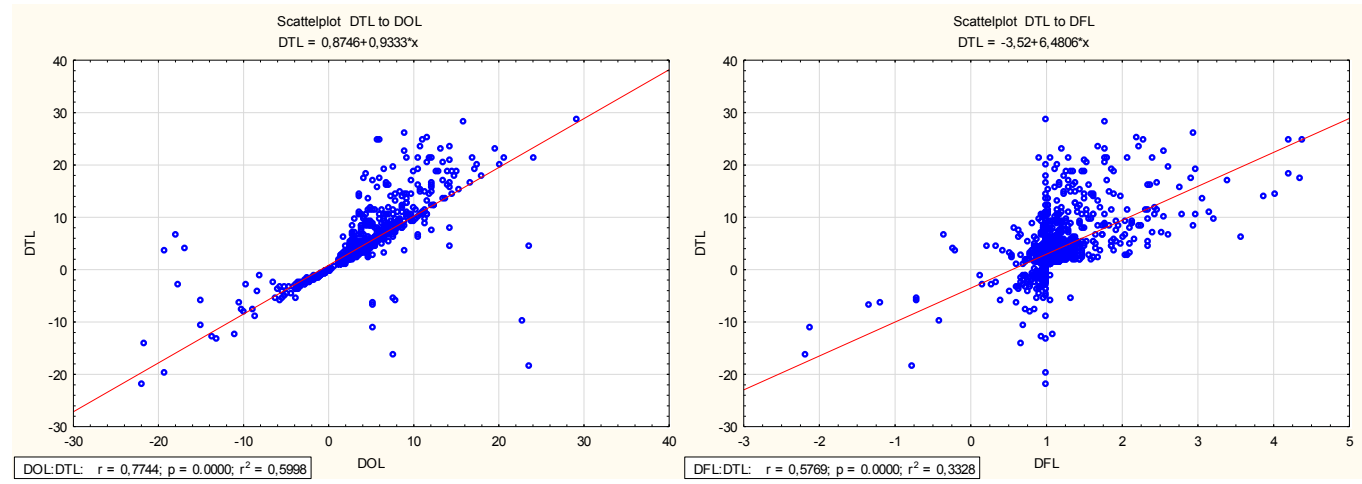

Fig. 2. Scatterplots of the DTL variable in relation to the DOL and the DFL of agricultural enterprises in 2005-2013.

Source: own study.

In 2010-2013, the total leverage dropped further to 2.92-3.92, which was caused primarily by the reduction in the operational risk, which is measured using the degree of operating leverage and also, to a smaller extent, using the decrease in the financial risk expressed by the degree of financial leverage. In 2013, the degree of operating leverage decreased to 3.76, and the degree of financial leverage to 1.04. A relative drop in the risk determined on the basis of degrees of leverage resulted from the significant growth in operating revenue and the improvement in the operating profit ratio of the analysed agricultural enterprises. Such a trend was related to the significant increase in the stock of land held by the studied entities in 2010-2012 (Zabolotnyy, 2016).

The diversity of the degree of operating leverage of agricultural enterprises in the studied period was generally caused by the significant changes to the gross margin ratio (GMR) with comparable fixed costs ratio (FCR). In 2005-2009, the 
average gross margin ratio decreased from $39.5 \%$ to $38.0 \%$, and in $2010-2013$, this ratio was in the range of $40.2-41 \%$. The ratio of fixed costs to operating income was $26.5-30.6 \%$ in the analysed period. This meant that in the earliest years of the studied period, the agricultural enterprises were characterised by lower operating profit compared to the revenue and fixed costs. This resulted in an increase in the operational risk measured using the degree of operating leverage. Moreover, in 2005-2009, the net interest rates were higher than later on, which indicated higher burden related to costs of financing, equity multipliers were also higher, which suggests higher level of debt among agricultural enterprises. In 2005-2009, the average net interest rates were in the range of $2-2.5 \%$, while in $2010-2.5 \%-$ at $-0.2-1.2 \%$. The equity multiplier decreased from 1.47 in 2009 to 1.28 in 2013 . This indicates higher financial risk of agricultural enterprises in the first years of the analysed period. In 2009-2013, the improvement in the gross margin ratio and the decrease in the level of debt and the cost of interest contributed to the decrease in both the degree of operating leverage and the degree of financial leverage and indicated a lower risk of agricultural enterprises. There is a need to emphasise that, from the perspective of the total business risk, the efficiency of asset use, measured using the asset productivity ratio, was less important to agricultural enterprises because the higher asset productivity ratios did not contribute to the decrease in the degree of leverage in 2005-2009, and relatively lower ratios did not cause a significant rise in it.

In order to confirm the conclusions concerning the links between the degrees of leverage and the components contributing to them, the correlation coefficients were calculated for the analysed variables of agricultural enterprises. For the purpose of correlation analysis, the studied population was additionally divided into two groups, i.e. enterprises that generated operating loss (negative operating profit ratio) and enterprises characterised by profitable operations (positive operating profit ratio) (Table 3 and 4 ).

Table 3

Coefficient of correlation between the degrees of leverage and the components contributing to them in profitable agricultural enterprises in 2005-2013

\begin{tabular}{|c|c|c|c|c|c|}
\hline Variable & $\begin{array}{l}\text { Gross margin } \\
\text { ratio }\end{array}$ & $\begin{array}{l}\text { Fixed costs } \\
\text { ratio }\end{array}$ & $\begin{array}{c}\text { Interest rate } \\
\text { on borrowed capital }\end{array}$ & $\begin{array}{l}\text { Asset turnover } \\
\text { ratio }\end{array}$ & $\begin{array}{c}\text { Equity } \\
\text { multiplier }\end{array}$ \\
\hline \multirow{2}{*}{$\begin{array}{l}\text { Operating } \\
\text { leverage }\end{array}$} & -0.1950 & 0.5313 & 0.0030 & 0.1847 & 0.0428 \\
\hline & $p=0.000$ & $p=0.00$ & $\mathrm{p}=0.917$ & $p=0.000$ & $\mathrm{p}=0.139$ \\
\hline \multirow{2}{*}{$\begin{array}{l}\text { Financial } \\
\text { leverage }\end{array}$} & -0.1545 & 0.0050 & 0.0997 & -0.0112 & 0.2242 \\
\hline & $p=0.000$ & $\mathrm{p}=0.864$ & $p=0.001$ & $\mathrm{p}=0.698$ & $p=0.000$ \\
\hline \multirow{2}{*}{$\begin{array}{l}\text { Total } \\
\text { leverage }\end{array}$} & -0.2032 & 0.4227 & 0.0401 & 0.1441 & 0.0990 \\
\hline & $p=0.000$ & $p=0.00$ & $p=0.166$ & $p=0.000$ & $p=0.001$ \\
\hline
\end{tabular}

Source: own study. 
In the group of agricultural enterprises generating operating profit, the coefficients of correlation between the degrees of leverage and the gross margin ratio were negative, while the coefficients of correlation between the degrees of leverage, interest rate, asset productivity ratio and the equity multiplier were positive.

Table 4

Coefficient of correlation between the degrees of leverage and the components contributing to them in agricultural enterprises generating loss in 2005-2013

\begin{tabular}{|c|c|c|c|c|c|}
\hline Variable & $\begin{array}{l}\text { Gross margin } \\
\text { ratio }\end{array}$ & $\begin{array}{l}\text { Fixed costs } \\
\text { ratio }\end{array}$ & $\begin{array}{l}\text { Interest rate on } \\
\text { borrowed capital }\end{array}$ & $\begin{array}{l}\text { Asset turnover } \\
\text { ratio }\end{array}$ & $\begin{array}{l}\text { Equity } \\
\text { multiplier }\end{array}$ \\
\hline \multirow{2}{*}{$\begin{array}{l}\text { Operating } \\
\text { leverage }\end{array}$} & -0.3274 & 0.2620 & 0.1279 & -0.1637 & -0.0060 \\
\hline & $p=0.000$ & $p=0.000$ & $\mathrm{p}=0.093$ & $p=0.031$ & $\mathrm{p}=0.938$ \\
\hline \multirow{2}{*}{$\begin{array}{l}\text { Financial } \\
\text { leverage }\end{array}$} & -0.1289 & 0.1829 & 0.2191 & 0.0399 & -0.0850 \\
\hline & $\mathrm{p}=0.090$ & $p=0.016$ & $p=0.004$ & $\mathrm{p}=0.601$ & $\mathrm{p}=0.265$ \\
\hline \multirow{2}{*}{$\begin{array}{l}\text { Total } \\
\text { leverage }\end{array}$} & -0.3192 & 0.1150 & -0.0389 & -0.1716 & 0.0926 \\
\hline & $p=0.000$ & $\mathrm{p}=0.131$ & $\mathrm{p}=0.611$ & $p=0.024$ & $\mathrm{p}=0.224$ \\
\hline
\end{tabular}

Source: own study.

In agricultural enterprises characterised by operating loss, the strength and direction of correlations between the analysed variables were similar. Only the asset productivity ratio showed negative correlation with the degree of leverage in the population of enterprises sustaining loss, which was compatible with the theoretical assumptions. The correlation analysis has shown that as the gross margin ratio grew, the degree of total leverage diminished. But then, an increase in the fixed costs ratio, interest rate, asset productivity ratio (for profitable enterprises) and the equity multiplier contributed to an increase in the degree of leverage. Among profitable enterprises, the observed correlation between the degrees of operating and total leverage and the fixed costs ratio was relatively stronger, which suggested higher sensitivity of the operating profit ratio of the entities in this group to the changes in these costs.

Among the enterprises generating loss, the relatively higher correlation coefficients were present between the degrees of operating leverage (-0.3274) and total leverage (-0.3192) and the gross margin ratio. This indicated relatively higher sensitivity of operating loss to change in operating revenue. Furthermore, among the loss-generating enterprises, a stronger correlation between the degree of financial leverage and the interest rate (0.2191) was observed, which suggested greater significance of the structure of financing to the risk of those entities. Among the profitable enterprises, though, there was a statistically significant positive correlation between the degree of financial leverage and the equity multiplier (0.2242).

In 2005-2013, the analysed agricultural enterprises carried out profitable activities (Table 5). In the studied period, the operating profit ratio (OPR) was at $11 \%$, the gross profit ratio (GPR) $-10.5 \%$, while the return on sales (ROS) $-9.4 \%$. 
Small differences between these ratios indicated a limited use of borrowed capital for financing and low burden of financial costs for agricultural enterprises, which could favourably affect their financial solvency (Wasilewski and Zabolotnyy, 2016).

Table 5

Profit ratios of agricultural enterprises (\%)

\begin{tabular}{lcccccccccc}
\hline \multirow{2}{*}{ Ratio } & \multicolumn{10}{c}{ Year } \\
\cline { 2 - 9 } & 2005 & 2006 & 2007 & 2008 & 2009 & 2010 & 2011 & 2012 & 2013 & Average \\
\hline $\begin{array}{l}\text { Operating } \\
\text { profit ratio }\end{array}$ & 9.8 & 9.3 & 14.0 & 5.9 & 8.5 & 14.4 & 11.4 & 12.3 & 10.7 & 11.0 \\
\hdashline $\begin{array}{l}\text { Gross profit } \\
\text { ratio }\end{array}$ & 8.8 & 8.5 & 13.2 & 4.9 & 7.4 & 14.0 & 11.4 & 12.0 & 10.3 & 10.5 \\
\hline $\begin{array}{l}\text { Return } \\
\text { on sales }\end{array}$ & 9.5 & 9.4 & 15.0 & 5.3 & 8.7 & 16.5 & 13.5 & 14.0 & 11.7 & 9.4 \\
\hline $\begin{array}{l}\text { Return } \\
\text { on equity }\end{array}$ & 9.5 & 8.1 & 12.6 & 4.4 & 6.8 & 12.0 & 9.5 & 10.1 & 7.8 & 9.1 \\
\hline $\begin{array}{l}\text { Return } \\
\text { on assets }\end{array}$ & 6.4 & 5.8 & 9.1 & 3.1 & 4.6 & 9.0 & 7.3 & 7.8 & 6.1 & 5.8 \\
\hline
\end{tabular}

Source: own study.

The average return on equity (ROE) was at $9.1 \%$, while the return on assets (ROA) was at $5.8 \%$. In the studied period, there was a clear correlation between the profitability ratios and the values characterising leverage mechanisms in agricultural enterprises. A higher risk, expressed by the degrees of leverage, was accompanied by lower profitability ratios of agricultural enterprises. In 2005-2009, when the degrees of leverage were the highest, the analysed entities had the lowest profitability ratios. The increase in the degree of total leverage from 4.49 in 2005 to 5.06 in 2009 was correlated to the drop in the operating profit ratio from $9.8 \%$ to $8.5 \%$, the gross profit ratio from $8.8 \%$ to $7.4 \%$, and the return on assets from $6.4 \%$ to $4.6 \%$. Moreover, in 2008, the maximum degree of total leverage was accompanied by the lowest profitability ratios. In 2010-2013, when the degree of total leverage was lower, the operating profit ratios and gross profit ratio were in the range of $10.7-14.4 \%$ and $10.3-14.0 \%$, respectively, the return on equity was in the rage of $7.8-12 \%$, and the return on assets was in the rage of $6.1-9 \%$. In this period, a downward trend was observed in the profitability ratios as the degree of total leverage grew.

The analysis of coefficients of correlation between the degrees of leverage and profit ratios reflected the presence of negative correlations between the level of risk expressed by the degrees of leverage and the profitability of agricultural enterprises in 2005-2013 (Table 6 and 7). 
Table 6

Coefficient of correlation between the degrees of leverage and profitability ratios in profitable agricultural enterprises in 2005-2013

\begin{tabular}{lccccc}
\hline \multicolumn{1}{c}{ Variable } & $\begin{array}{c}\text { Operating } \\
\text { profit ratio }\end{array}$ & $\begin{array}{c}\text { Gross profit } \\
\text { ratio }\end{array}$ & $\begin{array}{c}\text { Return } \\
\text { on equity }\end{array}$ & $\begin{array}{c}\text { Return } \\
\text { on assets }\end{array}$ & $\begin{array}{c}\text { Return } \\
\text { on sales }\end{array}$ \\
\hline $\begin{array}{l}\text { Operating } \\
\text { leverage }\end{array}$ & -0.6116 & -0.5937 & -0.3774 & -0.4353 & -0.4790 \\
\hdashline Financial & -0.1630 & -0.2381 & -0.1028 & -0.2054 & -0.1809 \\
leverage & $\mathrm{p}=.000$ & $\mathrm{p}=0.000$ & $\mathrm{p}=.000$ & $\mathrm{p}=.000$ & $\mathrm{p}=.000$ \\
\hdashline $\begin{array}{l}\text { Total } \\
\text { leverage }\end{array}$ & -0.5372 & -0.5434 & -0.3178 & -0.4063 & -0.4338 \\
\hline
\end{tabular}

Source: own study.

The increase in the degree of leverage caused a drop in the profitability of agricultural enterprises. Among the profitable enterprises, the strongest negative correlations were observed between the degree of operating and total leverage, and the operating profit ratio ( -0.6116 and -0.5372 , respectively) and gross profit ratio $(-0.5937$ and -0.5434 , respectively). Whereas the return on equity and return on assets ratio showed weaker negative correlation with the degree of leverage.

Table 7

Coefficient of correlation between the degrees of leverage and profitability ratios in agricultural enterprises generating loss in 2005-2013

\begin{tabular}{lccccc}
\hline \multicolumn{1}{c}{ Variable } & $\begin{array}{c}\text { Operating } \\
\text { profit ratio }\end{array}$ & $\begin{array}{c}\text { Gross profit } \\
\text { ratio }\end{array}$ & $\begin{array}{c}\text { Return } \\
\text { on equity }\end{array}$ & $\begin{array}{c}\text { Return } \\
\text { on assets }\end{array}$ & $\begin{array}{c}\text { Return } \\
\text { on sales }\end{array}$ \\
\hline $\begin{array}{l}\text { Operating } \\
\text { leverage }\end{array}$ & -0.5471 & -0.5369 & -0.3437 & -0.4813 & -0.4317 \\
$-\begin{array}{l}\mathrm{p}=0.000 \\
\text { Financial }\end{array}$ & -0.3028 & -0.2742 & -0.1735 & -0.2925 & -0.1915 \\
leverage & $\mathrm{p}=0.000$ & $\mathrm{p}=0.000$ & $\mathrm{p}=0.022$ & $\mathrm{p}=0.000$ & $\mathrm{p}=0.011$ \\
$-\begin{array}{l}\text { Total } \\
\text { leverage }\end{array}$ & -0.3797 & -0.3715 & -0.2420 & -0.3077 & -0.3010 \\
\hline
\end{tabular}

Source: own study.

Among the loss-generating enterprises, strongly negative correlations were observed between the degree of operating leverage and the operating profit ratio $(-0.5471)$, gross profit ratio $(-0.5359)$, return on assets $(-0.4813)$, and return on sales (-0.4317). Moreover, among the loss-generating enterprises, the negative correlation between the degree of financial leverage and profitability ratios was relatively stronger than in the case of profitable entities, which suggested relatively greater importance for the level of debt and the interest burden in this group. 


\section{Conclusions}

The study uses the degrees of operating and financial leverage to assess the risk of agricultural enterprises and discusses the characteristics of correlations between them and the financial efficiency ratios in 2005-2013. The following conclusions were formulated on the basis of the research:

1. What exerted the strongest impact on risk in agricultural enterprises measured using the degree of total leverage were the ratios related to operational activity characterising the profitability and the structure of costs. The parameters related to the manner of financing, such as the cost of interest and the level of debt, had a smaller effect on the level of risk in agricultural enterprises. This observation was compatible with the general interpretation of the specific nature of agricultural activities because the risk is believed to result from operational factors, while the farmers' aversion to liquidity risk causes a drop in the significance of risk determinants related to financing.

2. The decrease in the degree of total leverage in 2009-2013 resulted primarily from the increase in gross margin with the stable correlation between the fixed costs and the operating revenue of agricultural enterprises. At the same time, it was observed in the analogous period that the degree of financial leverage decreased, which was connected with the relative decrease in the cost of financing of agricultural enterprises.

3. The drop in the business risk measured using the degree of operating, financial and total leverage was accompanied by a rise in the profitability of agricultural enterprises. This correlation was caused by a strong increase in the operating risk in relation to the sales revenue, assets and equity with the similar structure of operating costs and costs of financing of the studied entities. It was observed that agricultural enterprises characterised by a high degree of leverage showed lower financial efficiency, which resulted from a small capability to generate operating profit.

4. Formulating management recommendations for specific entities requires the use of a dynamic approach to the analysis of leverage mechanisms. In such an approach, construction of various leverage scenarios will enable an analysis of the sensitivity of financial efficiency to business risk of the enterprise. On the one hand, an enterprise characterised by a high degree of leverage will be exposed to higher operating risk resulting from the adverse relation between the gross margin and fixed costs. On the other, the higher degree of leverage will indicate higher sensitivity of operating risk to change in sales revenue, which in case a favourable market scenario unfolds, allows risks and profitability ratios to be higher than in the case of enterprises with a low degree of leverage. It should be emphasised, however, that in this case, a negative scenario, leading to a drop in operating revenue, might contribute to significant losses. 


\section{References}

Bąk, M. (2011). Problemy behawioralne w rachunkowości przedsiębiorstwa. Zeszyty Naukowe Uniwersytetu Szczecińskiego, Finanse, Rynki Finansowe i Ubezpieczenia, no. 32, pp. 48-59.

Fedak, Z. (2016). Zamknięcie roku 2016. Warszawa: Rachunkowość.

Graham, J.R., Harvey, C.R. (2001). The theory and practice of corporate finance: evidence from the field. Journal of Financial Economics, vol. 60, issues 2-3, pp. 187-243.

Jajuga, K. (2009). Zarzadzanie ryzykiem. Warszawa: Wydawnictwo Naukowe PWN.

Jaworski, J. (2010). Zastosowanie dźwigni operacyjnej i finansowej w pomiarze wpływu inwestycji na ryzyko działalności małego przedsiębiorstwa. Zeszyty Naukowe Uniwersytetu Szczecińskiego, Finanse, Rynki Finansowe, Ubezpieczenia, no. 26, pp. 99-107.

Kinnunen, J. (2013). Risk-return trade-off and autocorrelation. Acta Universitatis Lappeenrantaensis, no. 551. Retrieved from: https://www.doria.fi, pp. 1-50.

Kowalczyk, J., Kusak, A. (2006). Decyzje finansowe firmy. Metody analizy. Warszawa: Wydawnictwo C.H. Beck.

Krawiec, M. (2011). Analiza wpływu metody szacowania zmienności historycznej na przewidywane ceny zbóż w modelu dwumianowym. Roczniki Nauk Rolniczych, Seria G, vol. 98, issue 1, pp. 40-46.

Kulawik, J. (2008). Efektywność finansowa w rolnictwie. Istota, pomiar i perspektywy. Zagadnienia Ekonomiki Rolnej, no. 2(315), pp. 33-53.

Markowitz, H. (1952). Portfolio selection. The Journal of Finance, vol. 7, no. 1. pp. 77-91.

Nowak, E. (2009). Statystyczne metody szacowania ryzyka w audycie wewnętrznym. Studia i Prace Wydziału Nauk Ekonomicznych i Zarządzania, no. 16, pp. 97-106.

Peterlik, M. (2012). Mapa ryzyka inwestycyjnego w branżach polskiej gospodarki. Gdańsk: Instytut Badań nad Gospodarką Rynkową.

Pomykalska, B., Pomykalski, P. (2007). Analiza finansowa przedsiębiorstwa. Warszawa: Wydawnictwo Naukowe PWN.

Rosa, A. (2011). Kredyty preferencyjne jako forma finansowania działalności rolniczej w Polsce. Zeszyty Naukowe SGGW - Ekonomika i Organizacja Gospodarki Żywnościowej, no. 91, pp. 97-106.

Sharpe, W.F. (1964). Capital Asset Prices: A Theory of Market Equilibrium under Conditions of Risk. The Journal of Finance, vol. 19, no. 3, pp. 425-442.

Shiller, R.J. (2003). From Efficient Markets Theory to Behavioral Finance. Journal of Economic Perspectives, vol. 17, no. 1, pp. 83-104.

Sibilski, W. (2010). Rentowność kapitałów własnych a dźwignia finansowa - aspekty teoretyczne oraz przykłady na bazie sprawozdań polskich przedsiębiorstw. Zeszyty Naukowe Uniwersytetu Szczecińskiego, Finanse, Rynki Finansowe, Ubezpieczenia, nr 26, pp. 215-227.

Sierpińska, M., Jachna, T. (2007). Metody podejmowania decyzji finansowych. Analizy przyktadów i przypadków. Warszawa: Wydawnictwo Naukowe PWN.

Sołtysiak, M. (2014). Menedżerowie w procesie zarządzania ryzykiem. Modern Management Review, MMR, vol. XIX, 21(2/2014), pp. 141-148.

Stępień, K. (2008). Rentowność a wyptacalność przedsiębiorstw. Warszawa: Difin.

Sulewski, P. (2015). Ekonomiczny wymiar ryzyka produkcyjnego w rolnictwie. Warszawa: Wydawnictwo SGGW.

Wasilewski, M., Juszczyk, M. (2015). Czynniki kształtujące decyzje inwestorów na rynku kapitałowym. Zeszyty Naukowe Uniwersytetu Szczecińskiego, nr 855, Finanse, Rynki Finansowe, Ubezpieczenia, no. 74, pp. 203-216. 
Wasilewski, M., Zabolotnyy, S. (2016). Relacje rentowności i płynności w przedsiębiorstwach rol-niczych. Finanse, Rynki Finansowe, Ubezpieczenia, no. 4, cz. 1, pp. 277-286.

Wędzki, D. (2003). Strategie płynności finansowej przedsiębiorstw. Kraków: Oficyna Ekonomiczna.

Zabolotnyy, S. (2016). Potencjał sprzedażowy a sytuacja finansowa przedsiębiorstw rolniczych - czy wielkość kształtuje efektywność? Finanse, Rynki Finansowe, Ubezpieczenia, no. 4, cz. 1, pp. 287-297. 


\title{
DŹWIGNIA OPERACYJNA I FINANSOWA JAKO MIARY RYZYKA W PRZEDSIĘBIORSTWACH ROLNICZYCH
}

\begin{abstract}
Abstrakt
Celem opracowania jest ocena poziomu ryzyka przedsiębiorstw rolniczych na podstawie dźwigni operacyjnej i finansowej, a także określenie relacji między tymi miarami a wskaźnikami efektywności finansowej. Badaniami objęto przedsiębiorstwa z bazy IERiGŻ-PIB z lat 2005-2013. Na kształtowanie ryzyka działalności przedsiębiorstw rolniczych największy wptyw miała dźwignia operacyjna, charakteryzujaca wrażliwość zysku operacyjnego na zmiany przychodów operacyjnych, z uwzględnieniem struktury kosztów. Dźwignia finansowa, określająca poziom zadtużenia i skalę obciązenia kosztami odsetek, w mniejszym stopniu wplywała na kształtowanie ryzyka przedsiębiorstw rolniczych. Podmioty o wysokiej dźwigni łącznej charakteryzowały się niższą efektywnościa finansowa, wynikajaca przede wszystkim z niskiej zdolności do generowania zysku operacyjnego.
\end{abstract}

Słowa kluczowe: dźwignia operacyjna, dźwignia finansowa, ryzyko, przedsiębiorstwo rolnicze.

Accepted for print: 19.04.2018.

Unless stated otherwise all the materials on the website are available under the Creative Commons Attribution 4.0 International license.

Some rights reserved to the Institute of Agricultural and Food Economics - National Research Institute.

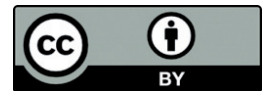

